\title{
New insights into the Gondwana breakup at the Southern South America by apatite fission-track analyses
}

\author{
Cristiane H. Gomes and Delia Almeida \\ Laboratório de Mineralogia e Petrografia, Universidade Federal do Pampa, Caçapava do Sul, 96570-000, Brazil \\ Correspondence: Cristiane H. Gomes (cristianegomes@unipampa.edu.br)
}

Received: 27 July 2018 - Revised: 6 January 2019 - Accepted: 7 January 2019 - Published: 21 January 2019

\begin{abstract}
Apatite fission-track (AFT) analyses, applied to Southern Brazil and Uruguay samples, was employed aiming to understand the low temperature history of the Dom Feliciano Belt Segment. The Dom Feliciano Belt formed during the Neoproterozoic to Early Paleozoic, linked to the Brasiliano/Pan-African Orogeny. Twenty-four samples were dated, and confined track lengths of twenty samples were measured. The spatial distribution of ages shows three domains with different evolution cut by shear zones and, or suture zones in the Dom Feliciano Belt. The Western Domain exhibits AFT ages $>250$ Ma (Permian to Devonian) while the Eastern Domain shows AFT ages $<230 \mathrm{Ma}$ (Paleogene to Triassic). In the Central Domain, the AFT ages range from $\sim 196$ to $130 \mathrm{Ma}$ (Jurassic to Early Cretaceous). The thermal modeling in the domains revealed a complex evolution, with cooling and reheating phases, and a denudation of $\sim 2600 \mathrm{~m}$. The AFT ages clearly postdate the Gondwanide, Paraná-Etendeka and Rio Grande Cone exhumation history of the Dom Feliciano Belt.
\end{abstract}

\section{Introduction}

The South America passive continental margin draw itself through several tectonic episodes that began in the Neoproterozoic (Almeida et al., 2000). These episodes are related to the breakup of continents, lithospheric and mantle dynamics. The transitions between Uruguay and Rio Grande do Sul State, Brazil, represents an evolutionary key area for the Gondwana Breakup of the lithospheric plates of South America and Africa. Several tectonic events took place during the Neoproterozoic to Cambrian, including accretionary orogenic processes that marked the transition from stable to unstable tectonic conditions. These processes, such as granite magmatism and metamorphism, (e.g. Piedra Alta and Nico Perez Terrane, in Uruguay, and Sul-rio-grandense Shield basement, in Brazil) have been recorded in many places (Bossi et al., 1998; Preciozzi et al., 1999; Chemale Jr. et al., 2012). Post-collisional processes occurred in the passive margin, mainly including foreland tectonics, extensionrelated intrusions, and isostatic adjustments (Chemale Jr. et al., 2005, 2012; Basei et al., 2008; Rapela et al., 2011; Saalmann et al., 2011). The Gondwana's formation occurred during Neoproterozoic to Cambrian by fusion of at least five cratons, among them the Rio de la Plata, Kalahari and Congo Cratons. The interactions among these cratons formed the Dom Feliciano Belt in Brazil and Uruguay (Philipp et al., 2016). In the Late Paleozoic, the Gondwanide Orogeny climate changes, including glaciations records in the Itararé Formation, Brazil, and tectonic affected the Gondwana margins. The cold climate gradually changes to temperate and humid atmosphere. The cold climate gradually changed to the temperate and humid atmosphere. A sedimentary sequence of siliciclastic rocks, associated with intrusion and extrusion of the Paraná-Edendeka Suit (Zalán et al., 1990), then overlain The Precambrian basement.

The tectonic evolution of the Uruguay and Rio Grande do Sul State in Brazil, is marked by metamorphic rocks and intrusions reworked of the Neoproterozoic, partly overlain by a thick sequence of Paraná rocks (Zalán et al., 1990). Milani et al. (1997) characterized six megasequences for the Paleozoic and Mesozoic intervals of the Parana Basin, where the depositional history was controlled by tectonism and climatic changes. Subparallel fault and fracture zones to the coastline were reactivated and over them the deposition of the Pelotas Basin (Fig. 1; Tomazelli and Willwock, 2000). Many of these records are known in Southern Brazil through thermochronological studies (Gallagher et al., 1994, 1995; Borba et al., 
2002; Tello et al., 2003; Hackspacher et al., 2004; Gomes, 2011; Hiruma et al., 2010; Franco-Magalhães et al., 2010; Siqueira-Ribeiro et al., 2011; Chemale Jr. et al., 2012; Karl et al., 2013; de Oliveira et al., 2016). These works suggest reactivation of the Precambrian structures and plate adjustment of breakup associated with the South Atlantic rift evolution. In addition to studies in restricted areas that suggest denudation in the NW cratonic interior of the Sul-rio-grandense Shield.

In order to improve the understanding of the Gondwana breakup at the Southern South America by thermochronological studies twenty-four new apatite fission-track data of granitic and gneiss rocks from the Uruguay and Southern Brazil were obtained. The results of this study provide a simplified model of the large-scale geodynamic evolution of the Dom Feliciano Belt Segment through time should be given, especially uplift and erosion (cooling), subsidence and magmatism (heating), and timing of the movement of large onshore faults and shear zones. It is a significant effect on the evolutionary history of the Sul-rio-grandense and Uruguay Shields.

\section{Geological Setting}

The Sul-rio-grandense and Uruguay Shields, situated in the Southwest Gondwana, originated from divergent movements between the two lithospheric plates of South America and Africa, with subsequent opening of the South Atlantic. These shields comprise rocks generated between Archean and Ordovician including Dom Feliciano Belt.

The Dom Feliciano Belt forms a discontinuous belt, bounded by NE-SW and NW-SE oriented regional Brasiliano Shear Zone (Fig. 1). This Belt is subdivided into three units by Fernandes et al. (1995), which are denominated Central, East, and West Dominions, from gravimetric data and separated by suture and shear zones. The Western Domain separated from the Central by NE-SW trending Caçapava Suture (Fig. 1), being formed by granitic-gneissic-magmatic rocks associated with multiple magmatic intrusions, which are predominantly located along the Major Gercino Shear Zone (Fig. 1; Chemale Jr. et al., 2012). The Major Gercino Shear Zone has a NE-SW oriented and is an important formation that separates the magmatic arc granites to the East and a folded supracrustal belt to the West. This domain is formed by Taquarembó and São Gabriel Terranes, Brazil (Fig. 1). The Taquarembó Terrane is composed of Paleoproterozoic granulites with protolith ages of $2.45 \mathrm{Ga}$ (Hartmann et al., 2000), several granite intrusions with age at 0.65$0.55 \mathrm{Ga}$ (Gastal et al., 2006) and Neoproterozoic to Eopaleozoic volcano-sedimentary rocks. The São Gabriel Terrane consists of ophiolite slabs, volcanic-arc-related rocks, granite-gneiss rocks with a Neoproterozoic juvenile signature, volcano-sedimentary rocks and late- to post-orogenic granite intrusions and volcano-sedimentary rocks of $\mathrm{Ca}$ - maquã Basin (Fig. 1; Chemale Jr., 2000; Hartmann et al., 2000; Saalmann et al., 2011).

The Central Domain is formed by part of the Camaquã Basin, Tijucas Terrane and a small part of the Pelotas Batholith (Fig. 1). The Tijucas Terrane (Fig. 1) is composed of metasedimentary rocks intercalated with metavolcanic rocks of the Porongos Complex with ages from ca. 0.5 to $2.8 \mathrm{Ga}$ (Chemale Jr., 2000; Saalmann et al., 2011; Basei et al., 2008; Gruber et al., 2016), granitic-gneissic rocks of the Encantadas Complex. The Encantadas Complex is interpreted as a Paleoproterozoic active continental arc (Saalmann et al., 2011; Philipp et al., 2008) and granitic intrusions and sedimentary rocks. The Pelotas Batholith bounded to the West by the Canguçu Shear Zone, is represented by granite rocks with ages of $650-550 \mathrm{Ma}$ and interpreted as a continental magmatic arc (Hartmann et al., 2000; Philipp and Machado, 2005), tectonically reworked in the Paleoproterozoic (Fernandes et al., 1995). The Camaquã Basin was generated in the late- to post-orogenic sedimentary cycles of the Brasiliano Orogeny in the Dom Feliciano Belt (Chemale Jr., 2000). The basin is NE-SW-elongated and is composed of the following four units:

1. Maricá Group dated at $601 \pm 13$ and $593 \pm 6 \mathrm{Ma}$ (Almeida et al., 2012; Paim et al., 2014);

2. Bom Jardim Group, whose age is constrained at $593 \pm$ 625 and $580 \pm 3.6 \mathrm{Ma}$ (Almeida et al., 2012);

3. Santa Bárbara Group dated at $553 \pm 5.4$ to $549 \pm 5 \mathrm{Ma}$ (Almeida et al., 2012); and,

4. Guaritas Group dated at $547 \pm 6.3 \mathrm{Ma}$ and $473.7 \pm$ 9.4 Ma (Almeida et al., 2012). The Eastern Domain separated from the Central by Canguçu-Major Gerciano Shear Zone (Fig. 1). This domain is formed by Pelotas Batholith, previously described.

In Uruguay (Fig. 1), the Dom Feliciano Belt separates into three different units by the Sierra Ballena Shear Zone:

\section{Nico Pérez Terrane \\ 2. Piedra Alta Terrane; and; \\ 3. Cuchila Dionísio-Pelotas Batholith (Fig. 1).}

The Sierra Ballena Shear Zone is part of a transcurrent system that divided the Dom Feliciano Belt into two different domains: Schist Belt and Granitic Belt (Bossi and Campal, 1992; Bossi et al., 1998; Teixeira et al., 1999). The Schist Belt is correlated in Brazil to the Porongos Group (Basei et al., 2008) and the Granite Belt is correlated with the Pelotas Batholith (Oyhantçabal et al., 2010; Philipp and Machado, 2005).

The Nico Pérez Terrane (Bossi and Campal, 1992), located East of the Sarandí del Yí Shear Zone (Fig. 1), composed of 

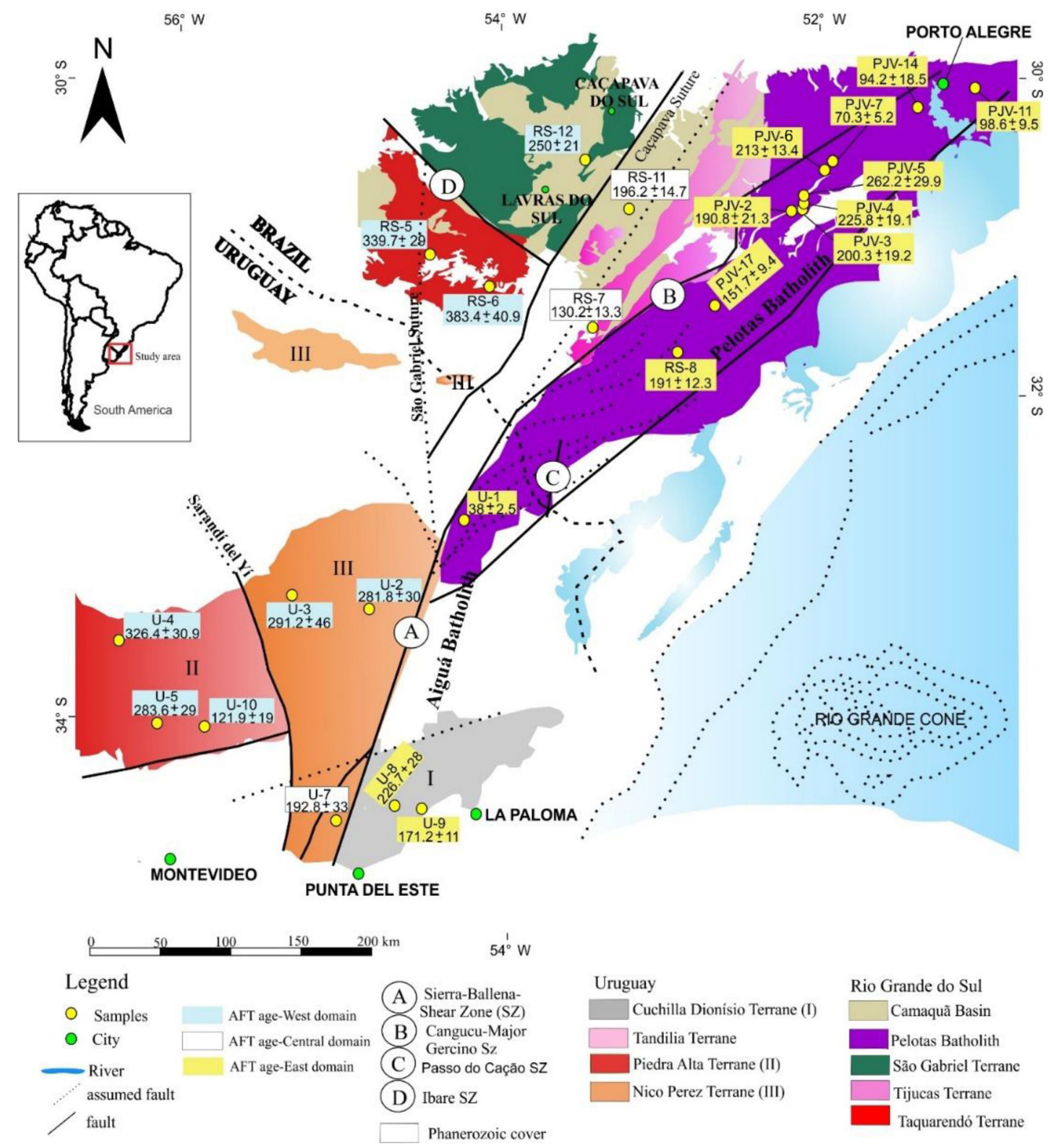

Figure 1. Simplified geological map of the Dom Feliciasno Belt in Uruguay and Rio Grande do Sul State, Brazil, and shear zones showing samples locations. Regional distribution of AFT ages $( \pm 1 \sigma)$ of the working area. In the blue boxes, AFT ages of West Domain of Dom Feliciano Belt; in the white boxes, AFT ages of Central Domain; and in the yellow boxes, AFT ages of East Domain (adapted after Castillo Lopes, 2009; Chemale Jr. et al., 2012; de Oliveira et al., 2016; and Gruber et al., 2016).

Archean remnants (>2.7 Ga, Hartmann et al., 2000) in Paleoproterozoic core and granitoids of ca. $1.8-1.5 \mathrm{Ga}$, orientated according to NNE-SSW. This terrane was intensely re- worked during events at ca. 3.1-3.0, 2.7, 2.2-2.0 Ga (Santos et al., 2003), 1.25 Ga (Bossi et al., 1998) and 540-530 Ma (Gaucher et al., 2011). 
The Piedra Alta Terrane defined by Bossi et al. (1998), located in the most Western part of Uruguay - West of the Sarandi del Yí Shear Zone, consists of three Paleoproterozoic belts, with E-W orientation and formed by metavolcanicsedimentary rocks intercalated by a granite-gneissic chronocorrelated (Dalla Salda et al., 1988; Cingolani et al., 1997; Hartmann et al., 2000). The Piedra Alta Terrane is the root of a juvenile Paleoproterozoic magmatic arc (2.2-2.0 Ga, Hartmann et al., 2002). According to Bossi et al. (1998), Campal and Schipilov (1999) and Teixeira et al. (1999) this terrane was tectonic stable at ca. $1.7 \mathrm{Ga}$. Mesoproterozoic ages were reported by Bossi et al. (1998) for the Sarandí del Yí Shear Zone suggesting that the Rio de la Plata Craton has been tectonically reworked.

The Cuchilla Dionísio-Aiguá Batholith (Gaucher et al., 2009), located to the East of the belt (Fig. 1), is characterized by Neoproterozoic to Paleoproterozoic granitoids and metagranitoids rocks (Bossi et al., 1998; Preciozzi et al., 1999) and limited from Nico Pérez Terrane by the Sierra Ballena Shear Zone (580-550 Ma, Ar-Ar, Oyhantçabal et al., 2010). This shear zone has continuity in Southern Brazil by the Canguçú Shear Zone (Fernandes and Koester, 1999), which was active at the end of the Neoproterozoic. The Sierra Ballena Shear Zone is marked by strong linear negative gravity anomalies (Hallinan et al., 1993) and probably controlled the intrusion of calc-alkaline granites (Bitencourt and Nardi, 1983). The Aiguá Batholith (Fig. 1) has been correlated with the Pelotas Batholith and is interpreted as the root of a Neoproterozoic magmatic arc.

Southern South America is affected by a very extensive glaciation at the Carboniferous-Permian (350-250 Ma) (Mcloughln, 2001) with the register of the Itararé Group (de Freitas-Brazil, 2004). At the same time, the Gondwanide Orogeny compressed and deformed the cratonic areas on the West and South Gondwana margins (e.g. Sierra de la Ventana, Uruguay) (Ramos, 1988) and formed the backbone of Uruguay and Rio Grande do Sul basement (Milani, 1997). In addition, the absence of records of sedimentation in Southern Brazil confirms that the basement was active (Milani, 1997). While in the Permian-Triassic the development of the lineaments with E-W direction parallels the zones of oceanic fractures, which can be related to the later development of the South Atlantic (Zalán et al., 1990). Parts of Gondwana rotated over the Southern during the Late Paleozoic (Mcloughln, 2001). The pre-existing structures (from Pre-Cambrian, Paleozoic and Triassic) collaborated with the South Atlantic opening and accommodated the deposition of Paraná Basin (Milani, 2000). The Paraná Basin has an elongated shape of almost $1100000 \mathrm{~km}^{2}$ and extends in a Southwest-Northeast direction throughout Brazilian Territory, Paraguay, Uruguay, and Argentina. According to Milani (1997) and Zerfass et al. (2003) this tectonic pattern is observed on the Gondwana Supersequence II (Rio Bonito, Palermo, Irati, Serra Alta, Rio do Rastro and Pirambóia formations). Franco-Magalhães et al. (2010) suggest that up to $\sim 6000 \mathrm{~m}$ of siliciclastic sedimentary rocks fill the old erosional topography with the Paraná flood basalt surface.

In the Neocomian (145-130 Ma) the rift phase began, which was followed by ascending intrusive bodies through fractures of the crust. Among them the Serra Geral magmatism with an age $134.5 \mathrm{Ma}$ (Pinto et al., 2011; Janasi et al., 2011), which used to ascend by older structures with NW-SE direction. After the Serra Geral magmatism the substrate of the region was shaped (Milani, 2000) and on subparallel faults to the coastline of the basement was deposited the Pelotas Basin (Tomazelli and Villwock, 2000). The Pelotas Basin is located in South Atlantic between Brazil and Uruguay. It is limited in its Northern part with Santos Basin through the Florianopolis Fracture Zone. In the Southern, it is limited by Chui Lineament, which separated it from Punta del Este Basin, Northern Uruguay. Structural data of these margins indicate that Pelotas Basin was controlled by tectonic stages of at South Atlantic pre-syn and post-rifting and affected by high-angle extensional faults (Bassetto et al., 2000; Contreras et al., 2011). Pelotas Basin covers more than $200000 \mathrm{~km}$ and includes Rio Grande Cone (Fig. 1). The Rio Grande Cone is a depositional feature formed during the Neogene and ultra-deep, which can reach 3600 m (Fontana, 1989).

The Late Cretaceous stable conditions have been recorded from fission-track ages (90-60 Ma, Gallagher et al., 1994), which refer to the sedimentation cycle in SE South America. Gallagher et al. (1994) suggest these thermochronological ages represent the Paraná-Etendeka volcanic suite event. These authors proposed an apatite fission-track (AFT) ageelevation relationship coupled with the occurrence of older ages (with AFT ages > $300 \mathrm{Ma}$ ) within very close geographic proximity to younger ones $(90-60 \mathrm{Ma})$. The exhumation and denudation of high-elevated areas during the Late Cretaceous, in response to the drift of South America over of the Trindade hotspot, were dated by thermochronological data and the AFT ages was close to $90 \mathrm{Ma}$ (Meisling et al., 2001; Tello et al., 2003; Hackspacher et al., 2004).

Data and information from tectonic events associated with residual weathering and sediments over paleosurfaces from Southeastern South America are compared to potential correlative sequences either in a continental interior as Santos Basin and to regional rifting basins. Uplift and ages are interpreted from AFT in literature. In the Pelotas Basin, the evidence of exhumation of the coastal mountain source area in the Paleogene is a thick sequence of sediments prograding outward, being known as Rio Grande Cone (Castillo Lopes, 2009). Franco-Magalhães et al. (2010) suggest that Paleocene-Eocene thermochronological ages indicate block faulting and exhumation of the flanks along of the Paleogene rifts. In the onshore, from Paleocene to Miocene (60-20 Ma), half-grabens trending NNE-SSW and are filled up by terrigenous sediments of more than $800 \mathrm{~m}$ (Melo et al., 1985; Almeida et al., 2000; Cobbold et al., 2001; Meisling et al., 2001; Salamuni et al., 2003; Karl et al., 2013). 
The South Atlantic opening still involves numerous uncertainties, like locations and magnitudes of overlaps between continental rocks, but it is accepted that initiated in the Southern Argentinean-African margins and propagated Northward to the Brazilian and African margins (Moulin et al., 2010).

\section{Analytical Procedures}

Twenty-four new samples were collected along the Western, Central and Eastern Domains of the Dom Feliciano Belt. We focused on the area where we considered there to be the best opportunities to identify the evolution of the Gondwana breakup. In the Western Domain, three samples were collected in the Piedra Alta Terrane, and three samples in the Nico Perez Terrane (Uruguay). In Southern Brazil, in this domain, two samples were collected in the Taquarembó Terrane and one sample to the Western of Caçapava Suture in the São Gabriel Terrane. In the Central Domain, one sample was collected to the East of Caçapava Suture in the Camaquã Basin, and one sample in the Tijucas Terrane and two samples to the West of Sierra Ballena Shear Zone in the Cuchilla Dionísio Terrane (Uruguay). In the Eastern Domain, ten samples were collected in the Pelotas Batholith (Brazil), one sample in the Aiguá Batholith and two samples in the Cuchilla Dionísio Terrane (Uruguay). In total, nine samples from Uruguay and 16 samples from Southern Brazil (Fig. 1; Table 1).

Apatite minerals were separated and isolated from each sample following procedures outlined in Dumitru (1999) using standard gravimetric and magnetic mineral separation techniques. The natural apatite was mounted in epoxy, polished and etched in $5 \mathrm{~N} \mathrm{HNO}_{3}$ for $25 \mathrm{~s}$ at $25^{\circ} \mathrm{C}$ to reveal the spontaneous fission-track. All AFT ages were performed using low-U mica sheets as external detector method (Gleadow and Lovering, 1977). Apatite samples were irradiated at the IPEN-CNEN nuclear reactor, São Paulo State, Brazil, with two glass neutron dosimeters (CN5 and CN1) with known uranium content together with Fish Canyon Tuff age standards and Durango apatite age standards (Hurford and Green, 1983; Green 1985). After irradiation, mica detectors were etched in $48 \% \mathrm{HF}$ for $18 \mathrm{~min}$ at $20^{\circ} \mathrm{C}$ to reveal the induced fission-tracks. The AFT analyses on all samples were performed at the Federal University of Rio Grande do Sul, Brazil, using a Zeiss Axioplan 2 imaging with Autoscan ${ }^{\circledR}$ system by the first author. AFT central ages were calculated according to the $\xi$-calibration method (Hurford, 1990; Hurford and Green, 1983). The AFT age errors are quoted at the $1 \sigma$ confidence level and were derived by the conventional method (Green, 1985). The $\chi 2$-squared test was used to quantify age homogeneity; when $P\left(\chi^{2}\right)>5 \%$, fissiontrack samples contain a single age population (Gallagher et al., 1995). The AFT age calculation, their dispersion, and distribution were obtained by the Trackkey ${ }^{\circledR}$ v. 4.2 Software (Dunkl, 2002).
Confined track lengths were measured on horizontal confined fission tracks following procedures Laslett et al. (1982) to construct an apatite fission-track length-frequency distribution. The apatite composition in term of chlorine and fluorine was carried out in the Department of Geology, Federal University of Rio de Janeiro State, Brazil, using a JEOL JXA-8230 Electron Microprobe with $15 \mathrm{kV}$ accelerating voltage, $25 \mathrm{nA}$ current, and 5-20 $\mu \mathrm{m}$ beam diameter.

The thermal histories were modeled using AFTSolve 1.4.1 (Ketcham et al., 2000). The time-temperature evolutions tested against the thermochronological data set are determined by using the published geological history of the area. The inversions modeling was run with 10000 randomly chosen time-temperature $(t--T)$ histories for each sample. Thus, the model paths were available to clearly differentiate between "goodness of fit" and "acceptable fit" solutions depending on the ages and lengths parameters and the geological background and cooling history of different areas. The initial inverse modeling is based on the best forward model revealed. We restricted the conditions for inversion modeling as follows:

a. as initial constraint the end of the Brasiliano Orogeny (ca. 550-450 Ma);

b. a large $t-T$ box was imposed with $T$ closed limits in the base of the apatite partial annealing zone temperature $\left(120^{\circ} \mathrm{C}\right)$ and at the paleosurface temperature $\left(20 \pm 10^{\circ} \mathrm{C}\right)$;

c. a present mean surface temperature of ca. $20 \pm 5^{\circ} \mathrm{C}$ provided the final modeling constraint. The annealing model used was of Ketcham et al. (1999), with Cl content values as a kinetic parameter and $D_{\mathrm{par}}(\mathrm{ppm})$ values (Donelick et al., 2005).

\section{Results}

\subsection{Apatite fission-track age distribution}

The AFT ages and confined track lengths measured from studied samples are presented in Table 1, Figs. 1 and 2. The thermal histories for all samples are presented in Figs. 35. AFT central ages measured in the West Domain range from $383.4 \pm 40.9$ (sample RS-6) to $250 \pm 21 \mathrm{Ma}$ (sample RS-12). In the Central Domain the AFT central ages range from $196.2 \pm 14.7 \mathrm{Ma}$ (sample RS-11) to $130.2 \pm 13.3 \mathrm{Ma}$ (sample RS-7), and in the East Domain the AFT central ages range from $262.2 \pm 29.9 \mathrm{Ma}$ (sample PJV-5) to $38 \pm 2.5 \mathrm{Ma}$ (sample U-1), which closely matches the range determined by de Oliveira et al. (2016) and Kollenz (2015) (Fig. 2). The AFT age distribution allows the separation of the Western Domain with older ages (>250 Ma) and the Eastern Domain with younger ages $(<230 \mathrm{Ma})$. One sample, taken from Pelotas Batholith revealed a central age of $262.2 \pm 29.9 \mathrm{Ma}$ (sample PJV-5) much larger than the AFT ages from this 


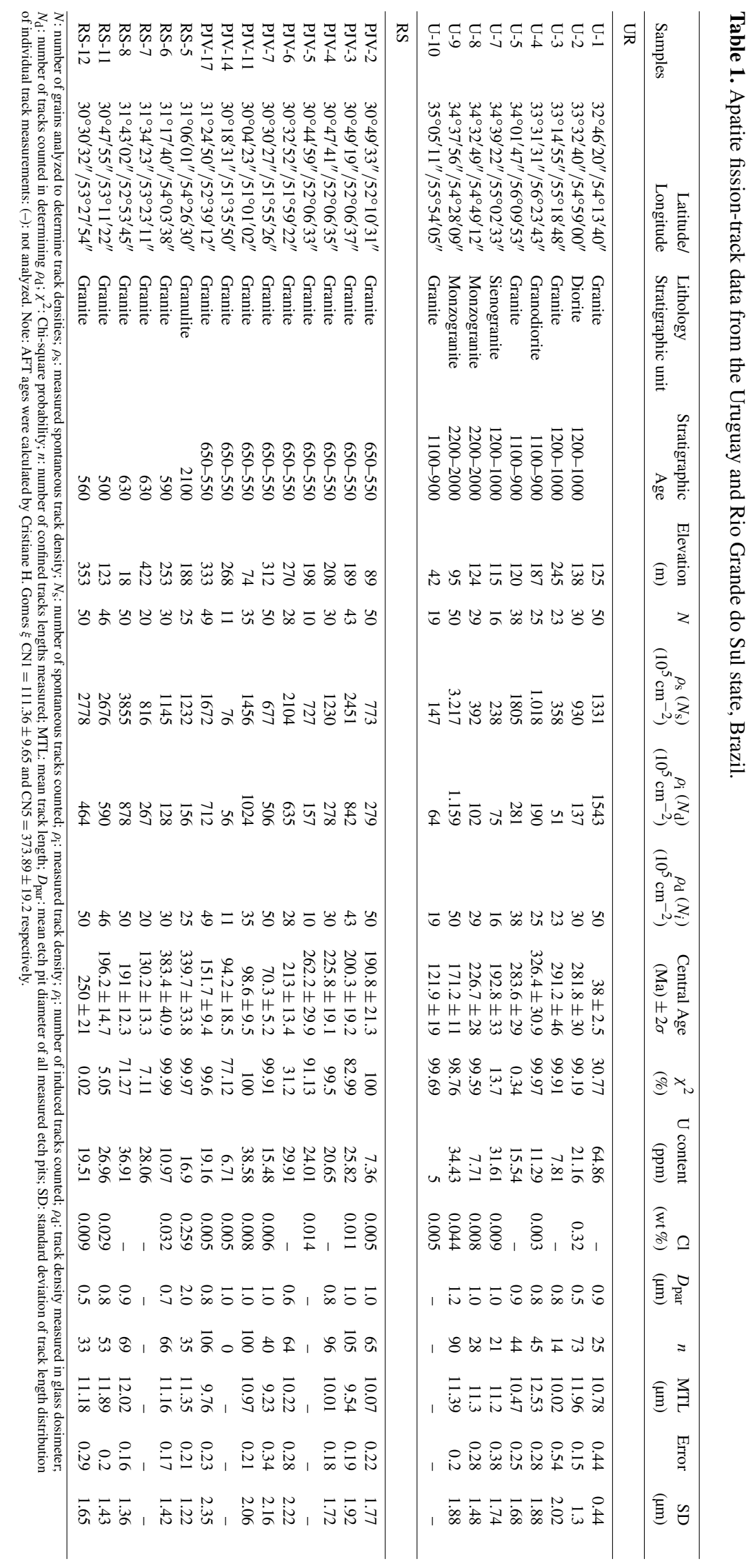




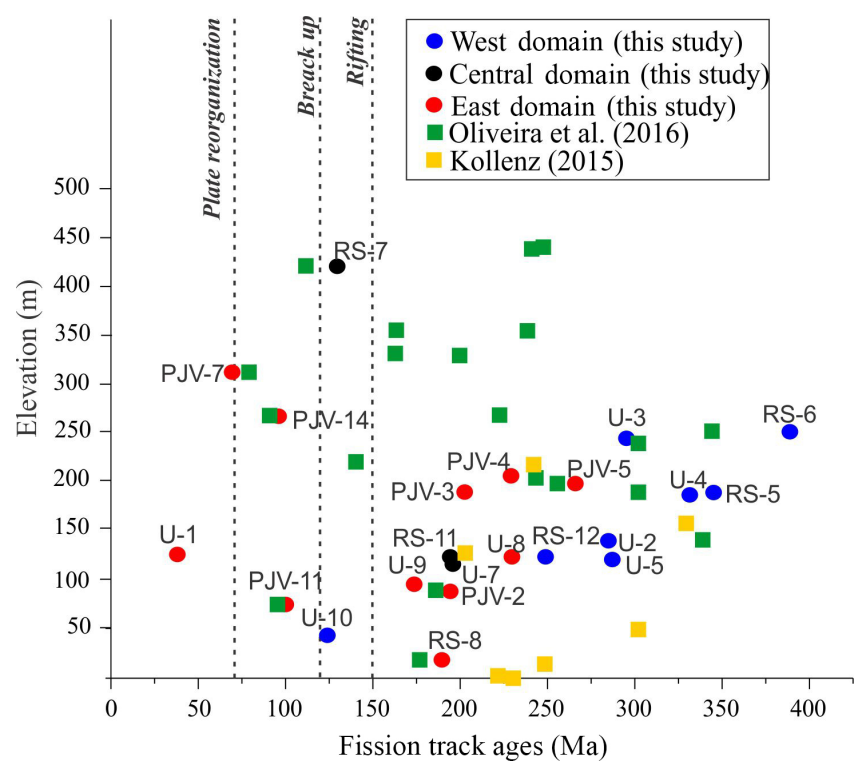

Figure 2. Variation of fission-track ages $(\mathrm{Ma})$ and elevation $(\mathrm{m})$ for the samples from Uruguay and Southern Brazil. Data from de Oliveira et al. (2016) and Kollenz (2015) to comparation.

domain. Zalán et al. (1990) suggest the development of the lineaments with E-W direction related to the South Atlantic rifting and the opening of the ocean in the Permian-Triassic. On the other hand, one sample from the Aiguá Batholith (Uruguay) revealed a central age of $38 \pm 2.5 \mathrm{Ma}$ (sample U1) much lower than the AFT ages from this domain. FrancoMagalhães et al. (2010) suggest that Paleocene-Eocene AFT ages indicate normal re-activation of old Brasiliano/Pan African Shear Zones along the Paleogene rifts. Thus, the Eastern Domain without these two samples, in particular, has AFT ages ranging from $226.7 \pm 28 \mathrm{Ma}$ (sample U-8) to $70.3 \pm 5.2 \mathrm{Ma}(\mathrm{PJV}-7)$.

\subsection{Confined track-lengths}

The dataset has more than 20 grains per sample (except for the samples U-7 and U-10 from Uruguay and, PJV-10 and PJV-14 from Brazil). The confined track lengths measured are unimodal with a range from 14 (sample U-3) to 106 (sample PJV-17), suggesting, in general, thermal histories with slow-cooling. In addition, they do not display the boomerang form, which is characteristic of a rapid cooling (Gallagher et al., 1994; Green, 1985). The Measured Track Length (MTL) ranges from $9.23 \mu \mathrm{m}$ (sample PJV-7) to $12.53 \mu \mathrm{m}$ (sample U-4) with an average of $10.8 \mu \mathrm{m}$. In the West Domain the MTL ranges from $10.02 \mu \mathrm{m}$ (sample U-3) to $12.53 \mu \mathrm{m}$ (sample U-4), and in the East Domain, the MTL ranges from $9.23 \mu \mathrm{m}$ (sample PJV-7) to $12.02 \mu \mathrm{m}$ (sample RS-8). According to Gallagher et al. (1994), the mean confined track length decreases slightly with age. The relationship between AFT age and the shape of the confined track length distributions is characteristic of samples that recorded various degrees of thermal annealing which occurred prior to a common episode of cooling (Gallagher et al., 1994).

Only one sample of the West, Central and East Domains did not present confined track length. The sample of the West Domain is located in the Piedra Alta Terrane, Uruguay, (U10) with an AFT age of $121.9 \pm 19$ (Fig. 1, Table 1). The sample of the Central Domain is located in the Tijucas Terrane, Brazil, (RS-7), whose AFT age is $130.2 \pm 13.3 \mathrm{Ma}$. The sample of the East Domain is located in the Pelotas Batholith, Brazil, (PJV-5), which shows AFT age of 262.2 \pm 29.9 Ma. These samples could not be modeled due to lack of confined track length, suggesting that apatites undergo high temperature $\left(>120^{\circ} \mathrm{C}\right)$. The fission-track will be annealed, and the fission-track system will recount. In the Early Permian, the Paraná Basin expanded considerably reaching Rio Grande do Sul State, Brazil, with structural modification in the substratum of the basin by subsidence and sedimentation.

The apatite chemical compositions were determined in order to establish the influence of fluorine and chlorine content on the annealing process. The analyzed grains are all fluorapatite (Donelick, 1991) with mean chlorine content range from 0.003 to $0.259 \mathrm{wt} \%$ and low resistance to annealing (O'Sullivan and Parrish, 1995).

\subsection{Age-elevation}

The correlation between AFT ages and elevation study here show old ages often occur within very close geographic proximity to young ones. All AFT central ages are much younger than the Brasiliano/Pan-African Orogeny that affected the Sul-rio-grandense Shield and Uruguay rocks before $500 \mathrm{Ma}$. The collective AFT dataset from Uruguay shows a systematic correlation between AFT age and elevation (Fig. 2). This relationship indicates a positive correlation between elevation and distance West and East of the Sierra Ballena Shear Zone, with an apparent uplift rate calculated of $40 \mathrm{~m} \mathrm{Ma}^{-1}$ during the Eocene. We, therefore, interpret this relationship as the reflection of the regional topography which is characterized by an elevated interior plateau separated from the coastal region by a Sierra Ballena Shear Zone. Based on geomorphology, the Sierra Ballena Shear Zone has separated into three sectors: Southern, Central and Northern. The Northern and Southern sectors are a strong contrast between the quartz mylonites and mylonitic porphyries of the shear zone (Schist Belt), which are more resistant to weathering, and the country rocks. In the central sector, the Granite Belt (Aiguá Batholith) and the low relief are associated with Mesozoic Basin (Oyhantçabal et al., 2010). This implies that the Uruguay region probably attained positive relief during the Late Cretaceous. During the Paleocene, the area was eroded and exhumed, which probably contributed to fill basins formed by rifting (Oyhantçabal et al., 2010). However, only the U-1 sample has an AFT age of $38 \pm 2.5 \mathrm{Ma}$ indicating that it was cooling during uplift and erosion in the 

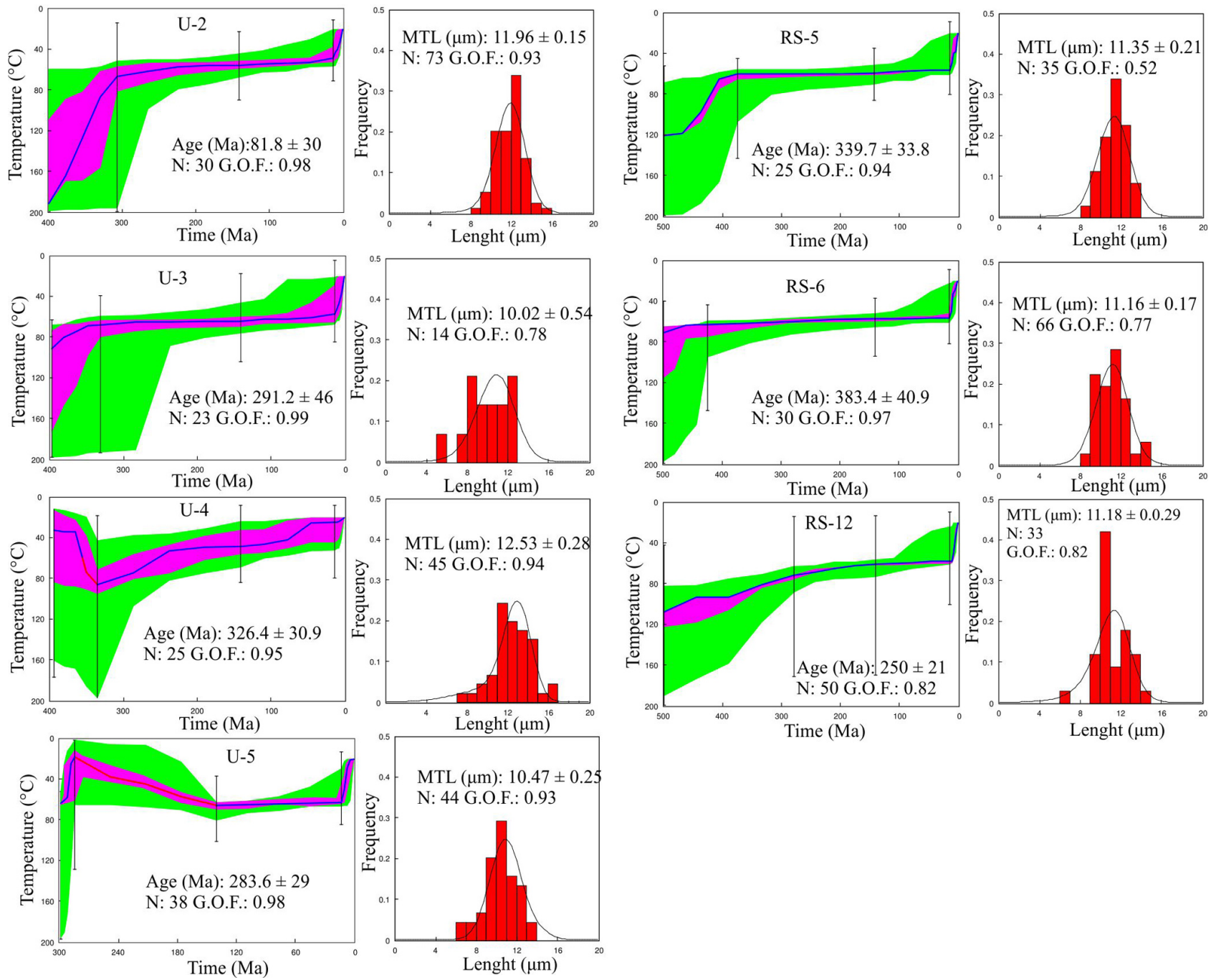

Figure 3. Thermal history of samples from the Western Domain. The numerical modelling used the software code AFTSolve (Ketcham et al., 1999). The temperature and time paths and the confined track length distributions are overlain by a calculated probability density function (best fit). The diagram on the left show four different fits: green paths are the acceptable fit; pink paths are the goodness of fits; and blue-red line is the best fit. The red line represents the moment of the heating. G.O.F.: goodness of fit, $N$ : number of single grain ages and measured track length (MTL).

Eocene, at about the time that Rio Grande Cone was formed in the Pelotas Basin (Castillo Lopes, 2009).

In Southern Brazil, the correlation between AFT age and elevation (Fig. 2) is not obviously related to age and distance to the coast, through the ages show a tendency to increase with altitude. The majority of the samples were collected from elevations $<353 \mathrm{~m}$; although only one sample from somewhat higher elevation $(422 \mathrm{~m})$ was collected from the summit surfaces of the Canguçu Shear Zone (Table 1, Fig. 2).

\subsection{The thermal modeling results}

The thermochronological data exhibit a complex thermal history at the Uruguay and Brazilian margins, which had record in the Permo-Carboniferous and Gondwanide Orogeny (Figs. 3, 4 and 5). For example, the Uruguay registers heating processes in the Anisian-Tithonian to Aptian, possibly associated with the Jurassic-Cretaceous continental rifting that affected the region. Already in Southern Brazil the thermochronological data show the Paraná Basin deposition, the Serra Geral magmatism, and the Rio Grande Cone evolution. The thermal modeling shows that the presently exposed rocks of Uruguay and Southern Brazil were at temperatures around $70^{\circ} \mathrm{C}$ during the Jurassic-Cretaceous period. In this way, the rocks present at the surface were at depths of at least $\sim 2360 \mathrm{~m}$ at that time, for a paleogeothermal gradient of $25^{\circ} \mathrm{C} \mathrm{km}^{-1}$ (Raab et al., 2002; Luft et al., 2005; Tinker et al., 2008). It could be assumed that the thermal modeling 

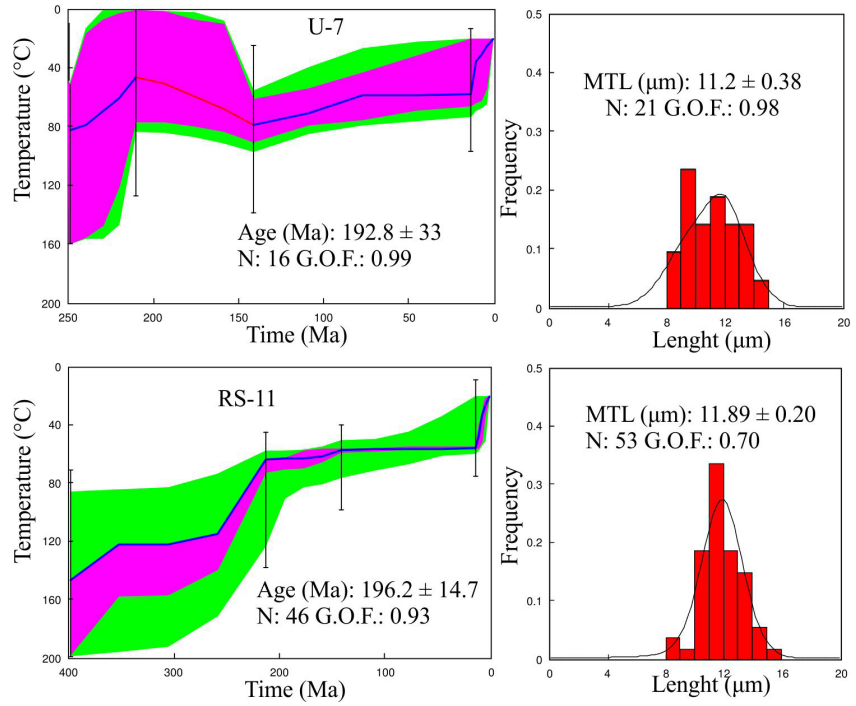

Figure 4. Thermal history of samples from the Central Domain. For detailed description see caption of Fig. 3.

results reflect ongoing slow exhumation during the JurassicCretaceous. In addition, our confined track length data, presenting a wide distribution and short mean values (Table 1) could be a result of continuous slow cooling from temperatures in excess of $120^{\circ} \mathrm{C}$ to surface temperatures (Gleadow, 1986).

The Western Domain of Dom Feliciano Belt (Fig. 3) is characterized by an initial very fast period of cooling during the Cambrian from 120 to $60^{\circ} \mathrm{C}$ in the Taquarembó Terrane, Brazil (sample RS-5). During the Devonian from 200 to $70^{\circ} \mathrm{C}$ (sample U-2) and 90 to $70^{\circ} \mathrm{C}$ (sample U-3) in the Nico Perez Terrane, Uruguay. This was followed by a slow period of cooling to the Carboniferous-Permian from 70 to $60^{\circ} \mathrm{C}$ (Fig. 3). After a final, a very fast period of cooling in the Eocene to Oligocene to almost surface temperatures $\left(\sim 25^{\circ} \mathrm{C}\right)$. In the Devonian, the Piedra Alta Terrane is characterized by a rapid period of reheating from 30 to $80^{\circ} \mathrm{C}$ (sample U-4), which extends until the Late Jurassic as a slow period of reheating from 20 to $80^{\circ} \mathrm{C}$ (sample U-5).

The Central Domain of Dom Feliciano Belt (Fig. 4) displays slow and fast intercalated periods of cooling since the Devonian from 80 to $50^{\circ} \mathrm{C}$ in the Camaquã Basin (sample RS-11). However, the Cuchilla Dionísio Terrane, Uruguay (sample U-7), reveals a very fast period of cooling at the Triassic boundary from 80 to $50^{\circ} \mathrm{C}$, followed by a period of reheating in the Jurassic to 50 to $80^{\circ} \mathrm{C}$ (Fig. 4). After a final slow period of cooling in the Cretaceous-Paleogene to 80 to $60^{\circ} \mathrm{C}$. In the Eocene to Oligocene both Camaquã Basin, Brazil, and Cuchilla Dionísio Terrane, Uruguay, are characterized by a fast period of cooling to almost surface temperatures $\left(\sim 25^{\circ} \mathrm{C}\right)$.

The East Domain of Dom Feliciano Belt is characterized by periods of variation of temperature mainly in the Pelotas
Batholith. During the Ordovician-Late Carboniferous, the region presents initial periods of reheating from 110 to $170{ }^{\circ} \mathrm{C}$ (samples PJV-2, PJV-4 and PJV-17, Fig. 5), at the same time a fast-moderate cooling from 170 to $30^{\circ} \mathrm{C}$ (sample PJV6 ) occurs. In the Jurassic-Cretaceous a slow cooling is observed $\left(\sim 60^{\circ} \mathrm{C}\right)$ in both the Pelotas Batholith, Brazil, and in Cuchilla Dionísio Terrane, Uruguay. However, the Pelotas Batholith reveals a very fast period of heating in the Triassic (sample PJV-6) that extends to the Oligocene (sample PJV$4)$.

\section{Discussion and interpretation}

The exposes rocks from the uplifted region at the South America passive continental margin in Southern Brazil and Uruguay are formed at the Paleoproterozoic due to the collision of Rio de la Plata, Kalahari and Congo cratons reworking. There were subsidence and exhumation which marked the tectonic evolution in Southern Brazil and Uruguay (Almeida et al., 2000; Gomes, 2011; Rapela et al., 2011; Saalmann et al., 2011; Chemale Jr. et al., 2012; Philipp et al., 2016). In this crustal domain, during the Gondwana Orogeny, important NNE-S-trending lineaments were generated (e.g. Sierra Ballena-Major Gercino, Sarandí del Yí in Uruguay and, Canguçu and Ibaré in Brazil) and the oblique movement of the collision tectonic blocks formed the main suture zones (Caçapava, Porto Alegre and São Gabriel in Brazil). These movements are related to both a tangential tectonic regime and a transcurrent, which are characterized by continentcontinent collision and low-angle planar structures (Fernandes et al., 1995).

\subsection{Ordovician to Permian (Gondwanide Orogeny)}

The first episode of cooling was recorded in the samples of the Piedra Alta and Nico Perez Terranes in Uruguay and, Taquarembó and São Gabriel Terranes in Southern Brazil from $\sim 500 \mathrm{Ma}$ extending up to $260 \mathrm{Ma}$ (Fig. 3). This age interval coincides with three known events in the region of the Western Domain of the Dom Feliciano Belt, being:

a. the time of cooling through the $300-350{ }^{\circ} \mathrm{C}$ internal from the biotites and muscovites whose $\mathrm{K}-\mathrm{Ar}$ age is ca. $570 \mathrm{Ma}$ from mylonites of Major Gercino Shear Zone in Uruguay (McDougall and Harrison, 1999). This age indicates later brittle reactivation of the shear zones in Devonian;

b. the reactivation of faults related to a late thermaltectonic event, which have an age range of 540 to $530 \mathrm{Ma}$ (mica Ar-Ar and biotite K-Ar), and were probably responsible for the formation of the Camaquã Basin (Philipp and Machado, 2005);

c. the shear zone reactivations can be associated with the stabilization phase with low exhumation events of tec- 

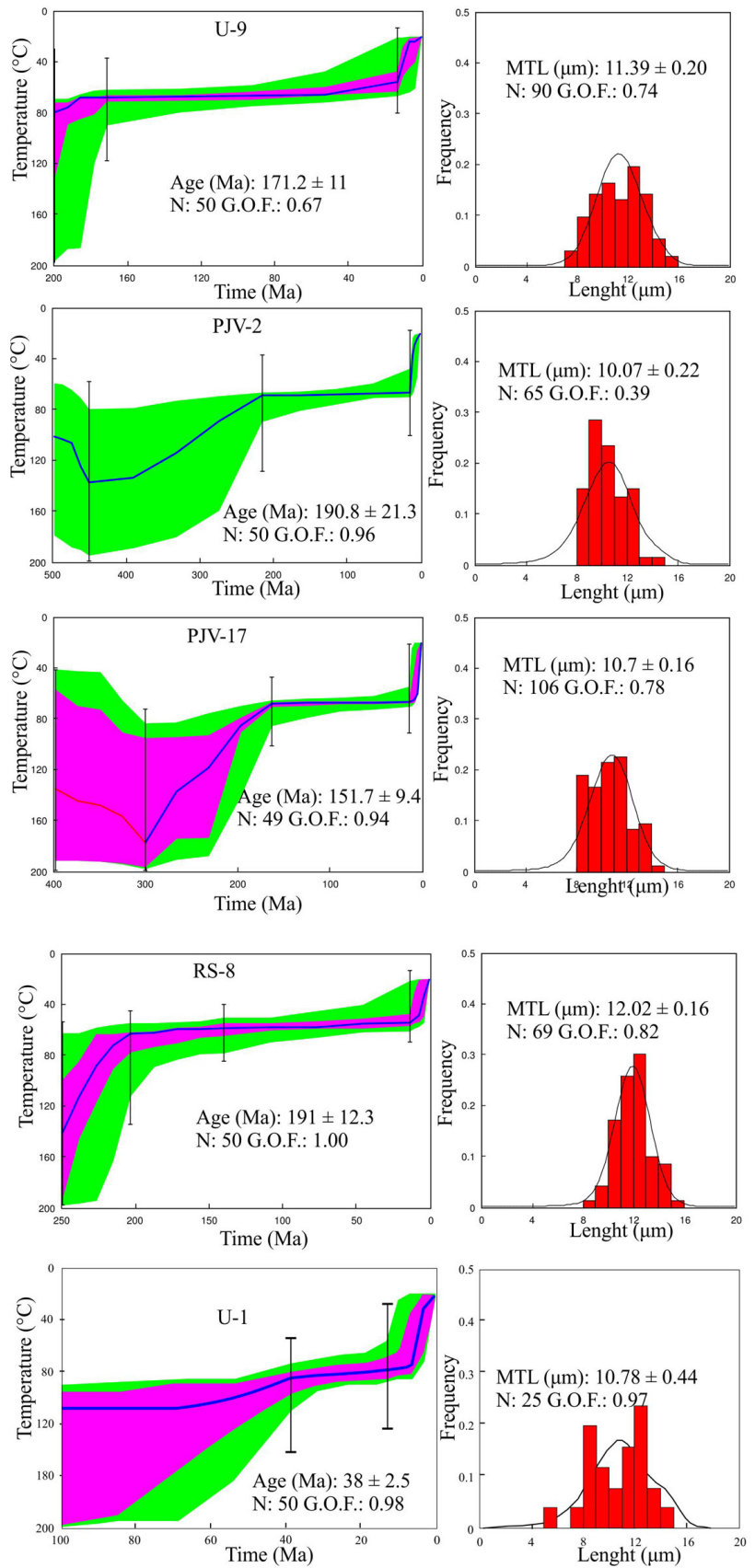
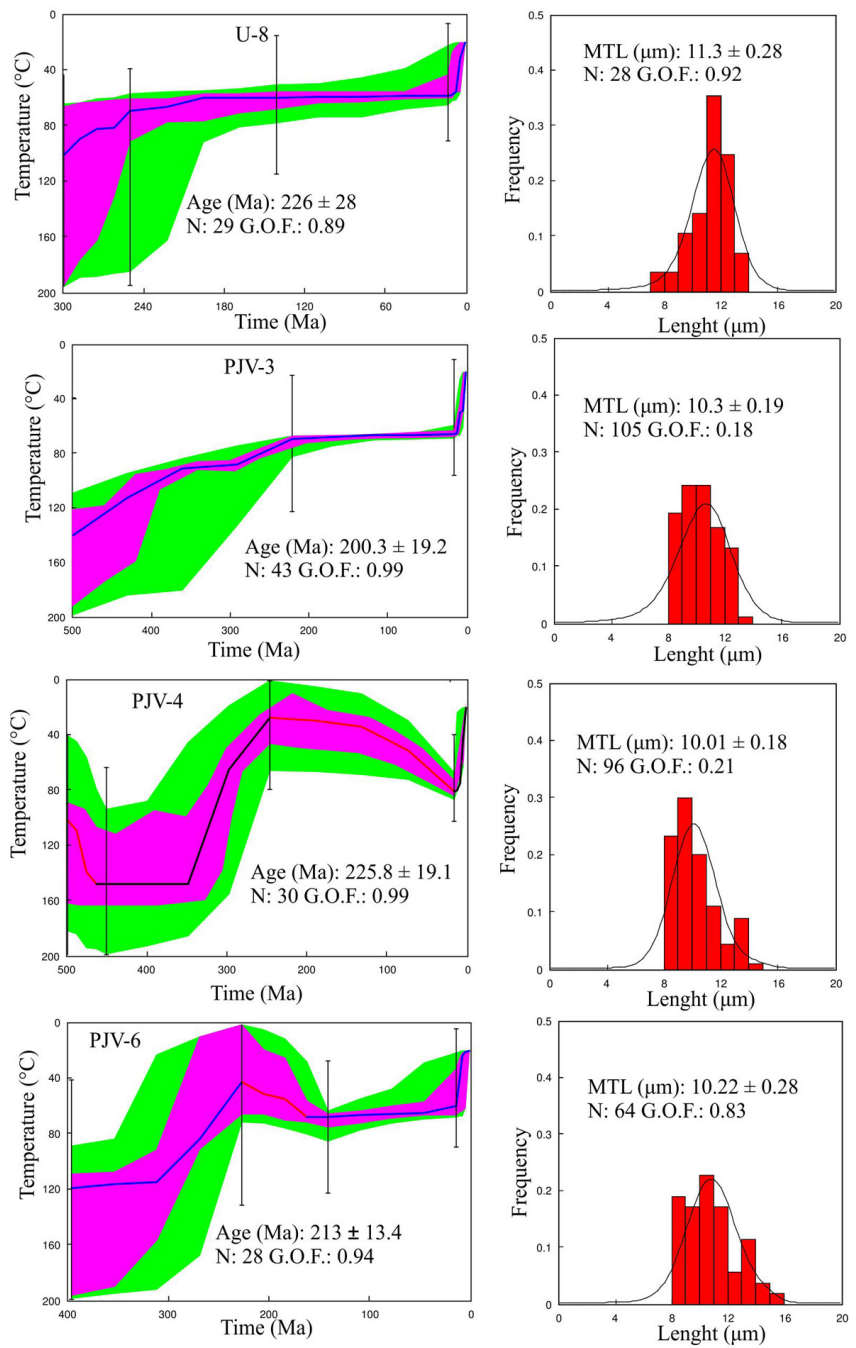

Figure 5. Thermal history of samples from the East Domain. For detailed description see caption of Fig. 3.

tonic blocks correlated to the Paraná Basin evolution (Hackspacher et al., 2004). Enhanced cooling around $500-260 \mathrm{Ma}$, as indicated by the model (Fig. 3), could explain a denudation rate around $40-560 \mathrm{~m}$ in Southern Brazil (sample RS-6) and Uruguay (sample U-2), respectively. At the same time the temperature decreased from 200 to $60^{\circ} \mathrm{C}$, corresponding to a greater extensive glaciation (Mcloughln, 2001).

Moreover, we interpret the age of $262.2 \pm 29.9 \mathrm{Ma}$ (sample PJV-5) in the East Domain as the reflex of the development of lineaments with E-W direction related to the South Atlantic rifting and the opening of the ocean in the Permian-Triassic.

\subsection{Triassic to Jurassic (Post Gondwanide Orogeny)}

The AFT ages in the Central and East Domains imply a phase of cooling between 250-150 Ma (Figs. 4 and 5). The samples coming from regions as Camaquã Basin, Tijucas Terrane and Pelotas Batholith in Brazil, and Cuchilla Dionísio Terrane in Uruguay close to tectonic lines (Sierra Ballena, 
Canguçu, Major Gercino, Passo do Cação Shear Zones and, Caçapava and Porto Alegre Sutures), which are interpreted as reactivated zones (Philipp and Machado, 2005; Oyhantçabal et al., 2010; Gomes, 2011; de Oliveira et al., 2016). Some authors suggest that shear zone reactivations, in the Triassic (206 and 230 Ma), observed in mylonites at Northern Major Gercino Shear Zone are associated with a thermal pulse connected to an early phase of the opening of the South Atlantic (Passarelli et al., 2010). The Major Gercino Shear Zone is a crustal discontinuity that encompasses several anastomosed shear zones, striking NNE and NE with dominant transcurrent kinematics and in which syn-tectonic calc-alkaline, peraluminous and alkaline granites occurred (Oyhantçabal et al., 2010). The Triassic is associated with the formation of a NWtrending grabens, which are probably related to a relaxation of the compressional stress field.

The episodes during the Late Triassic and the Early Jurassic $(\sim 200 \mathrm{Ma})$ would be related to the distensive regime that operated along the Gondwana margin in the Paleozoic (Keeley and Light, 1993; Milani, 2000; Zerfass et al., 2003), which formed Graben-type basins in Southern South America. In this case this structure is probably associated with thermal pulse to an early phase of the opening of the South Atlantic Ocean (Melo et al., 1985; Riccomini et al., 1989; Almeida and Carneiro, 1998; Almeida et al., 2000; Cobbold et al., 2001; Meisling et al., 2001; Salamuni et al., 2003; Tello et al., 2003). Reheating events during Late Triassic and Early Jurassic $(\sim 200 \mathrm{Ma})$ is denoted by a temperature increase of $\sim 60-80^{\circ} \mathrm{C}$ in the Nico Perez Terrane (Fig. 4, sample U-7) and $50-70^{\circ} \mathrm{C}$ in the Pelotas Batholith (Fig. 5, sample PJV-6).

\subsection{Cretaceous to Recent (Syn- and Post- Gondwana rift evolution)}

The second episode of cooling recorded by most samples of the Dom Feliciano Belt, which started in the Cretaceous (150-70 Ma), was slow and continuous (Figs. 3-5) without significant sedimentation taking place with less than $240 \mathrm{~m}$. The rift phase is followed by ascending intrusive bodies through fractures of the crust. Among them the Serra Geral magmatism, which was ascended by older structures with NW-SE direction. The Jurassic-Cretaceous reactivation that culminated in the Serra Geral magmatism, which is related to the Paraná-Etendeka event occurring 134.5 Ma (Pinto et al., 2011; Janasi et al., 2011), shows to be the main event that provided enough heat to erase the fission-tracks of the samples located in the Tijucas Terrane (South Brazil) and Piedra Alta Terrane (Uruguay) (e.g. samples RS-7 and U-10). In this case, the AFT ages of $130.2 \pm 13.3 \mathrm{Ma}$ (sample RS-7) were interpreted as the age of spilled magmatism over Southern Brazil and as age of reactivation of old faults in Uruguay during the rifting extension.

The Central Domain, in the Nico Perez Terrane (sample U-2, Fig. 4), and in the East Domain, in the Pelotas Batholith (sample PJV-6, Fig. 5), shows slight reheating episodes at temperatures up to $80^{\circ} \mathrm{C}$ between 210 and $150 \mathrm{Ma}$. Thus, the AFT age obtained here is close to this magmatism episode where these samples recorded the South Atlantic syn-rift phase.

The AFT ages of the sample from Pelotas Batholith (samples PJV-7, PJV-14, and PJV-11, Fig. 1) possibly denotes the flexural readjustments, cooling and mechanical accommodation of the oceanic crust of the post-rift phase (Tomazelli and Villwock, 2000$)$ during the Cretaceous ( $\sim 70 \mathrm{Ma})$.

Finally, during the Eocene $(\sim 40 \mathrm{Ma})$, a denudation episode was recorded in most of the studied samples. The calculated denudation rates are between 32 to $66 \mathrm{~m} \mathrm{Ma}^{-1}$ in Uruguay and up to $45 \mathrm{~m} \mathrm{Ma}^{-1}$ in Southern Brazil. This restricted interval, in a certain way, may be correlated with the formation of the Rio Grande Cone. According to Fontana (1989), structures related to gravitational movements must have affected the region thermally over the years. During this period, there was a substantial increase of detrital input in the Brazilian continental margin (Barboza et al., 2008), with the development of several deltaic progradation systems over time (Della-Fávera, 2001). Modeling of samples was also shown for the case that the rock was exhumed above the PAZ during Eocene. If the temperature increase (i.e. $\sim 20^{\circ} \mathrm{C}$ ) in the Paleocene to Eocene was solely driven by gravity loading, the thickness of the $\sim 1800 \mathrm{~m}$. In addition, the AFT of Aiguá Batholith ( $38 \pm 2.5 \mathrm{Ma}$; sample U-1) indicates normal re-activation of old Brasiliano/Pan African Shear Zones along of the Paleogene rifts.

Summarizing, thermal models support the possibility that the basement of the Dom Feliciano Belt experienced a first cooling during Ordovician to Permian (500$260 \mathrm{Ma})$. After, was followed by tectonic activity and exhumation/denudation during the Triassic to Jurassic (260$150 \mathrm{Ma})$. During the Cretaceous occurred a phase of stagnation, renewed sedimentation which caused subsidence and reheating of parts of the Dom Feliciano Belt. In the Late Cretaceous to recent gave rise to higher exhumation rates (40 Ma).

\section{Conclusion}

The thermochronological study from AFT in samples from Uruguay and Southern Brazil divided between three domains of Dom Feliciano Belt namely, West, Central and East can be identified with differentiated exhumation and complex thermal history of the distinct domains. These three domains are formed at the Paleoproterozoic rocks and separated by old reactivated fracture zones. The thermochronological data indicate AFT ages range from $383.4 \pm 40.9$ to $38 \pm 2.5 \mathrm{Ma}$, which closely matches the range in previous publications. AFT central ages measured in the West Domain range from $383.4 \pm 40.9$ to $250 \pm 21 \mathrm{Ma}$. In the Central Domain the AFT central ages range from $196.2 \pm 14.7$ to $130.2 \pm 13.3 \mathrm{Ma}$, and in the East Domain, the AFT central ages range from 
$262.2 \pm 29.9$ to $38 \pm 2.5 \mathrm{Ma}$. These data allowed to separate the Western Domain with older ages $(>250 \mathrm{Ma})$ of the Eastern Domain, which presents younger ages $(<230 \mathrm{Ma})$.

Based on thermal history modeling, the Western Domain cooled down very fast in the Cambrian in the Taquarembó Terrane, Brazil, and during the Devonian in the Nico Perez Terrane, Uruguay, followed by the Central Domain in the Camaquã Basin, Brazil. The Eastern Domain began to register fast-moderate cooling only from the Ordovician in the Pelotas Batholith, at the same time as occurs reheating in this area. However, in the Western Domain, a very fast period of reheating occurred in the Piedra Alta Terrane, Uruguay. During the Carboniferous-Permian a slow period of cooling is registered in the Western Domain. This phase is assumed to be triggered by the Gondwanide Orogeny and Gondwana II (Brasiliano Orogeny).

Mesozoic time is characterized in the Dom Feliciano Belt by very complex temperature evolution with fast and slow cooling and reheating. The samples of Western Domain show fast cooling in the Triassic, followed by reheating especially the samples just below the Piedra Alta Terrane. During the Jurassic, the East Domain undergoes a slow cooling in the Pelotas Batholith, Brazil, and Cuchilla Dionísio Terrane, Uruguay. The Pelotas Batholith also show a reheating period that begins in the Jurassic and extends until the Oligocene. These thermal histories can be related to the formation of NW-trending grabens and Paraná-Etendeka event. After almost stable conditions up to Miocene times a final very rapid cooling occurred.

In the Eocene $(\sim 40 \mathrm{Ma})$, the Dom Feliciano Belt registered a very large denudation in the Eastern Domain. Applied from the thermal gradients an overburden of $2640 \mathrm{~m}$ can be assumed, suggesting a correlation with the Rio Grande Cone. In addition, indicate normal re-activation of old Brasiliano/Pan African Shear Zones along of the Paleogene rifts.

Data availability. No data sets were used in this article.

Author contributions. CHG was responsible for all the experimental work and results. CHG and DdPMdA were responsible for the preparation and scientific discussions.

Competing interests. The authors declare that they have no conflict of interest.

Special issue statement. This article is part of the special issue "Earth surveillance and space-based monitoring of the environment: integrated approaches". It is a result of the EGU General Assembly 2018, Vienna, Austria, 8-13 April 2018.
Acknowledgements. Cristiane H. Gomes acknowledges the National Council for Scientific and Technological Development - CNPq for the scholarship programme with the reference 141178/2010-8. The authors acknowledge to CPRM and Votorantin Metal Company for borehole samples, and Project FAURGS/FINEP/CTPETRO 21.01.0310.00 for basement samples. We are grateful for reviews of Farid Chemale Jr. and anonymous reviewer that led to improvements in the manuscript.

Edited by: Silas Michaelides

Reviewed by: two anonymous referees

\section{References}

Almeida, D. P. M., Chemale Jr., F., and Machado, A.: Late to PostOrogenic Brasiliano Pan-African Volcano-Sedimentary Basins in the Dom Feliciano Belt, Southernmost Brazil, Petrology, 73130, 2012.

Almeida, F. F. M. and Carneiro, C. D. R.: Origem e evolução da serra do mar, Rev. Bras. Geo., 28, 135-150, 1998.

Almeida, F. F. M., Brito Neves, B. B., and Carneiro, C. D. R.: The origin and evolution of the South American platform, Earth Sci. Rev., 50, 77-111, 2000.

Barboza, E. G., Ros, A. M. L. C. C., and Ayup-Zouain, R.: Cronoestratigrafia da Bacia de Pelotas: uma revisão das sequências deposicionais, Grave, Porto Alegre, 6, 125-138, 2008.

Basei, M. A. S., Frimmel, H. E., Nutman, A. P., and Preciozzi, F.: West Gondwana amalgamation based on detrital zircon ages from Neoproterozoic Ribeira and Dom Feliciano belts of South America and comparison with coeval sequences from SW Africa, in: West Gondwana, Pre-Cenozoic correlations across the South Atlantic region, edited by: Pankhurst, R. J., Trouw, R. A. J., Brito Neves, B. B., and de Wit, M. J., Geological Society, Special Publication, 294, 239-256, 2008.

Bassetto, M., Alkmin, F. F., Szatmari, P., and Mohriak, W. U.: The oceanic segment of the southern Brazilian margim: morphostructural domains and their tectonic significance, in: Atlantic Rifts and Continental Margins, Geophys. Monogr. Series, 115, 235-259, 2000.

Bitencourt, M. F. and Nardi, L. V. S.: Late- to Post-collisional Brasiliano Magmatism in Southernmost Brazil, Anais da Academia Brasileira de Ciências, 65, 3-16, 1993.

Borba, A. W., Vignol-Lelarge, L., and Mizusaki, A. M. P.: Uplift and denudation of the Caçapava do Sul granitoids (southern Brazil) during late Paleozoic and Mesozoic: constraints from apatite fission-track data, J. South Am. Earth Sci., 15, 683-692, 2002.

Bossi, J. and Campal, N.: Magmatismo y tectônica transcorrente durante el Paleozoico Inferior en Uruguay, in: Paleozoico Inferior de Ibero-América, Extremadura, edited by: Gutiérrez Marco, J. G., Saavedra, J., Rábano, I., Universidad de Extremadura, 343356, 1992.

Bossi, J., Ferrando, L., Montaña, J., Campal, N., Morales, H., Gancio, F., Schipilov, A., Piñeyro, D., and Sprechmann, P.: Carta Geológica del Uruguay, Escala 1 : 500000, 1998.

Campal, N. and Schipilov, A.: The eastern edge of the Rio de la Plata Craton: A history of tangential collisions, P. Int. C Bas., 13, 33-48, 1999. 
Castillo Lopes, L. A.: Interpretação Sismoestratigráfica e Geomorfológica Sísmica do Cone de Rio Grande, Bacia de Pelotas, PhD, Programa de Pós-Graduação em Geociências, Porto Alegre, UFRGS, 2009.

Chemale Jr., F.: Evolução geológica do Escudo Sul-rio-grandense, in: Geologia e Estratigrafia do Rio Grande do Sul, Porto Alegre: CIGO/UFRGS, edited by: Holz, M. and De Ros, L. F., 13-52, 2000.

Chemale Jr., F., Ebert, H. D., Luft, J. R., and Mallmann, G.: Evolução tectônica e história térmica da margem SE do Brasil e W da África, Porto Alegre: FAURGS/FINEP/PETROBRAS, 1, 102-210, 2005.

Chemale Jr., F., Mallmann, G., Bitencourt, M. F., and Kawashita K.: Time constraints on magmatism along the Major Gercino Shear zone, Southern Brazil: implications for West Gondwana reconstruction, Gondwana Res., 22, 184-199, 2012.

Cingolani, C., Varela, R, Dalla Salda, L., Bossi, J., Campal, N., Piñeiro, D., and Schipilov, A.: Rb-Sr geochronology from the Río de La Plata craton, South American Symposium on Isotope Geology, Actas, 1, 73-75, 1997.

Cobbold, P. R., Meisling, K. E., and Mount, V. S.: Reactivation of an Obliquely Rifted Margin, Campos and Santos Basins, Southeastern Brazil, AAPG Bull., 11, 1925-1944, 2001.

Contreras, J., Zühlke, R., Bowman, S., and Bechstädt. T.: Seismic stratigraphy and subsidence analysis of the southern Brazilian margin (Campos, Santos and Pelotas basins), Mar. Pet. Geol., 27, 1952-1980, 2011.

Dalla Salda, L., Bossi, J., and Cingolani, C.: The Rio de La Plata cratonic region of South western Gondwana, Episodes, 11, 263269, 1988

de Freitas-Brasil, F. A.: Estratigrafia de sequências e processo diagenético: exemplos dos arenitos marinho-rasos da Formação Ponta Grossa, noroeste da Bacia do Paraná, Master Degrau, Programa de Pós-Graduação em Análise de Bacias e Faixas Móveis, UERJ, Rio de Janeiro, 2004.

Della Fávera, J. C.: Fundamentos de Estratigrafia Moderna, Rio de Janeiro, University of Rio de Janeiro State, 263 pp., 2001.

de Oliveira, C. H. E., Jelinek, A. R., Chemale Jr., F., and Bernet, M.: Evidence of post-Gondwana breakup in Southern Brazilian Shield: Insights from apatite and zircon fission track thermochronology, Tectonophysics, 666, 173-187, 2016.

Donelick, R. A.: Crystallographic orientation dependence of mean etchable fission track length in apatite: An empirical model and experimental observations, Am. Mineral., 76, 83-91, 1991.

Donelick, R. A., O'Sullivan, P. B., and Ketcham, R. A.: Apatite fission-track analysis, Rev. Mineral Geochem., 58, 49-94, 2005.

Dumitru, T. A.: Fission-track geochronology in: Quaternary Geochronology: Methods and Applications, AGU Ref. Shelf, 4, 131-159, 1999.

Dunkl, I.: TRACKKEY: a windows program for calculation and graphical presentation of fission track data, Comput. Geosci., 28, 3-12, 2002.

Fernandes, L. A. D. and Koester, E.: The Neoproterozoic Dorsal de Canguçu strike-slip shear zone: Its nature and role in the tectonic Evolution of Southern Brazil, J. Afr. Earth Sci., 29, 3-24, 1999.

Fernandes, L. A. D., Tommasi, A., and Porcher, C. C.: Deformapré-cambrien de Rio Grande do Sul (Brésil), Mode de gisement et Feliciano belt, J. South Am. Earth Sci., 5, 77-96, 1995.
Fontana, R. L.: Evidências geofísicas da presença de hidratos de gás na Bacia de Pelotas - Brasil, in: Congresso da Sociedade Brasileira de Geofísica, 1, Rio de Janeiro, Anais, 19-22 August, 234-248, 1989.

Franco-Magalhães, A. O. B., Hackspacher, P. C., and Saad, A. R.: Exumação tectônica e reativação de paleolineamentos no Arco de Ponta Grossa: termocronologia por traços de fissão em apatitas, Rev. Bras. Geoci., 40, 184-195, 2010.

Gallagher, K., Hawkesworth, C. J., and Mantovani, M. S. M.: The denudation history of the onshore continental margin SE Brazil inferred from apatite fission track data, J. Geophys. Res., 99, 18117-18145, 1994.

Gallagher, K., Hawkesworth, C. J., and Mantovani, M. S. M.: Denudation, fission track analysis and long-term evolution passive margin topography: application to the southeast Brazilian margin, J. South Am. Earth Sci., 8, 65-77, 1995.

Gastal, M. C. P., Lafon, J. M., Ferreira, J. F. F., Magro, J. F. U., Remus, M. V. D., and Sommer, C. A.: Reinterpretação do Complexo Intrusivo Lavras do Sul, RS, de acordo com os sistemas vulcano-plutônicos de subsidência. Parte 1: geologia, geofísica e geocronologia $\left({ }^{207} \mathrm{~Pb} /{ }^{206} \mathrm{~Pb}\right.$ e $\left.{ }^{206} \mathrm{~Pb} /{ }^{238} \mathrm{U}\right)$, Rev. Bras. Geoci., 36, 109-124, 2006.

Gaucher, C., Finney, S. C., Poiré, D. G., Valencia, V. A., Grove, M., Blanco, G., Chiglino, L., Pamoukaghlián, K., and Gómez Peral, L.: Detrital zircon ages of Neoproterozoic sedimentary successions in Uruguay and Argentina: Insights into the geological evolution of the Río de La Plata Craton, Precambr. Res., 167, 150 $170,2009$.

Gaucher, C., Frei, R., Chemale Jr., F., Frei, D., Bossi, J., Martinez, G., Chiglino, L., and Cernuschi, F.: Mesoproterozoic evolution of the Rio de la Plata Craton in Uruguay: at the heart of Rodinia?, Int. J. Earth Sci., 100, 273-288, 2011.

Gleadow, A. J. W.: Confined fission track lengths in apatite: a diagnostic tool for thermal history analysis, Contrib. Mineral. Petr., 94, 405-415, 1986.

Gleadow, A. J. W. and Lovering, J. F.: Geometry factor for external detectors in fission track dating, Nucl. Tracks Rad. Meas., 1, 99106, 1977.

Gomes, C. H.: História Térmica das regiões sul e sudeste da América do Sul: implicações na compartimentação geotectônica do Gondwana, Thesis, Universidade Federal do Rio Grande do Sul, Porto Alegre, 2011.

Green, P. F.: The relationship between track shortening and fission track age reduction in apatite, Combined influence of inherent stability, annealing anisotropy, length bias and system calibration, Earth Planet. Sc. Lett., 89, 335-352, 1985.

Gruber, L., Porcher, C. C., Koester, E., Bertotti, A. L., Lenz, C., Fernandes, L. A. D'A., and Remus, M. V. D.: Isotope geochemistry and geochronology of syndepositional volcanism in Porongos Metamorphic Complex, Santana da Boa Vista antiform, Dom Feliciano Belt, Brazil: Onset of an 800 Ma continental arc, JSE, 1, 202-221, 2016.

Hackspacher, P. C., Ribeiro, L. F. B., Ribeiro, M. C. S., Fetter, A. H., Hadler Neto, J. C., Tello, C. A. S., and Dantas, E. L.: Consolidation and breakup of the South American Platform in Southeastern Brazil: tectonothermal and denudation histories, Gondwana Res., 7, 91-101, 2004.

Hallinan, S., Mantovani, M. M., Shukowsky, W., and Braggion Jr., I.: Estrutura do Escudo Sul-Brasileiro: uma revisão através de 
dados gravimétricos e magnetométricos, Rev. Bras. Geoci., 23, 201-214, 1993.

Hartmann, L. A., Piñeyro, D., Bossi, J., Leite, J. A. D., and Mcnaughton, N. J.: Zircon U-Pb SHRIMP dating of Paleoproterozoic Isla Mala granitic magmatism in the Rio de La Plata Craton, Uruguay, J. South Am. Earth Sci., 13, 105-113, 2000.

Hartmann, L. A., Santos, J. O. S., Cingolani, C., and McNaughton, N.: Two Paleoproterozoic orogenies in the evolution of the Tandilia Belt, Buenos Aires, as evidenced by Zircon U-Pb SHRIMP geochronology, Int. Geol. Rev., 44, 528-543, 2002.

Hiruma, S. T., Riccomini, C., Modenesi-Gauttieri, M., Hackspacher, P. C., and Hadler N. J. C.: Denudation history of the Bocaina Plateau, Serra do Mar, southeastern Brazil: Relationships to Gondwana breakup a passive margin development, Gondwana Res., 18, 674-687, 2010.

Hurford, A. J.: Standardization of fission track dating calibration: Recommendation by the Fission Track Working Group of the I.U.G.S. Subcommission on Geochronology, Chem. Geol., 80, $171-178,1990$.

Hurford, A. J. and Green, P. F.: The zeta age calibration of fission track dating, Chem. Geol., 41, 285-317, 1983.

Janasi, V. A., Freitas, V. A., and Heaman, L. H.: The onset of flood volcanism, Northern Paraná Basin, Brazil: A precise U-Pb baddeleyite/zircon age for a Chapecó-type dacite, Earth Planet. Sc. Lett., 302, 147-153, 2011.

Karl, M., Glasmacher, U. A., Kollenz, S., Franco-Magalhães, A. O. B., Stockli, D. F., and Hackspacher, P. C.: Evolution of the South Atlantic passive continental margin in southern Brazil derived from zircon and apatite (U-Th-Sm)/He and fission-track data, Tectonophysics, 604, 224-244, 2013.

Keeley, M. L. and Light, M. P. R.: Basin evolution and prospectivity of the Argentine continental margin, J. Petrol. Geol., 16, 451464, 1993.

Ketcham, R. A., Donelick, R. A., and Carlson, W. D.: Variability of Apatite Fission-Track Annealing Kinetics: III. Extrapolation to Geologic Time Scales, Am. Mineral., 84, 1235-1255, 1999.

Ketcham, R. A., Donelick, R. A., and Donelick, M. B.: Aftsolve: a program for multikinetic modelling of apatite fission-track data, Geo. Mater. Res., 2, 1-32, 2000.

Kollenz, S.: Long term landscape evolution, cooling and exhumation history of the South American passive continental margin in NE Argentina \& SW Uruguay, Dissertation, Fakultät für Chemie und Geowissenschaften, Institut für Geowissenschaften, 2015.

Laslett, G. M., Gleadow, A. J. W., and Duddy, I. R.: The relationship between fission track length and track density in apatite, Nucl. Tracks Radiat. Meas., 9, 29-38, 1982.

Luft, F. F., Luft Jr., J. L., Chemale Jr., F., Lelarge, M. L. M. V., and Ávila, J. N.: Post-Gondwana break-up record constraints from apatite fission track thermochronology in NW Namibia, Radiat. Meas., 39, 675-679, 2005.

Mcloughln, S.: The breakup history of Gondwana and its impact on pre-Cenozoic floristic provincialism, Aust. J. Bot, 49, 271-300, 2001.

McDougall, I. and Harrison, T. M.: Geochronology and Thermochronology by the ${ }^{40} \mathrm{Ar} /{ }^{39} \mathrm{Ar}$ Method, 2nd ed., Oxford, Oxford University Press, 269 pp., 1999.

Meisling, K. E., Cobbold, P. R., and Mount, V. S.: Segmentation of an obliquely rifted margin, Campos and Santos basins, southeastern Brazil, AAPG Bull., 85, 1903-1924, 2001.
Melo, M. S., Riccomini, C., Hasui, Y., Almeida, F. F. M., and Coimbra, A. M.: Geologia e evolução do sistema de bacias tafrogênicas continentais do sudeste do Brasil, Rev. Bras. Geoci., 15, 193201, 1985.

Milani, A. J.: Evolução tectono-estratigráfica da bacia do paraná e seu relacionamento com a geodinâmica fanerozóica do gondwana sul-ocidental, PhD Tese, CPGEO/UFRGS, 1997.

Milani, E. J.: Geodinâmica fanerozóica do Gondwana sul-ocidental e a evolução geológica da Bacia do Paraná, in: Geologia do Rio Grande do Sul, Porto Alegre: CIGO/UFRGS, 275-302, 2000.

Moulin, M., Aslanian, D., and Unternehr, P.: A new starting point for the South and Equatorial Atlantic Ocean, Earth Sci. Rev., 98, 1-37, 2010.

O'Sullivan, P. B. and Parrish, R. R.: The importance of apatite composition and single-grain ages when interpreting fission track data from plutonic rocks: a case study from the Coast Ranges, British Columbia, Earth Planet. Sc. Lett., 132, 213-224, 1995.

Oyhantçabal, P., Siegesmund, S., and Wemmer, K.: The Rio de la Plata Craton: a review of units, boundaries, ages and isotopic signature, Int. J. Earth Sci., 100, 201-220, 2010.

Paim, P. S. G., Chemale Jr. F., and Wildner, W.: Estágios evolutivos da Bacia do Camaquã (RS), Ciência e Natura, 36, 183-193, 2014.

Passarelli, C. R., Basei, M. A. S., Wemmer, K., Siga Jr., O., and Oyhantçabal, P.: Major shear zones of southern Brazil and Uruguay: escape tectonic in the eastern border of Rio de La plata and Paranapanema cratons during the Western Gondwana amalgamation, Int. J. Earth Sci., 100, 391-414, 2010.

Pinto, V. M., Hartmann, L. A., Mcnaughton, N. J., and Wildner, W.: Zircon U-Pb geochronology from the Paraná bimodal volcanic province support a brief eruptive cycle at $\sim 135 \mathrm{Ma}$, Chem. Geol., 281, 93-102, 2011.

Philipp, R. P. and Machado, R.: Suítes graníticas do batólito Pelotas no Rio Grande do Sul: petrografia, tectônica e aspectos petrogenéticos, Rev. Bras. Geoci., 31, 257-266, 2005.

Philipp, R. P., Lusa, M., and Nardi, L. V. S.: Geochemistry and petrology of dioritic, tonalitic and trondhjemitic gneisses from Encantadas Complex, Santana da Boa Vista, southernmost Brazil, a Paleoproterozoic continental-arc magmatism, An. Acad. Bras. Ciênc, 80, 1-14, 2008.

Philipp, R. P., Pimentel, M. M., and Chemale Jr., F.: Tectonic evolution of the Dom Feliciano Belt in Southern Brazil: Geological relationships and U-Pb geochronology, Braz. J. Geol., 46, 83104, 2016.

Preciozzi, F. L., Peel, E., Bettucci, L. S., Basei, M. A. S., Aubet, N., and Peçoits, E.: El Terreno Piedra Alta: Una unidad geotectonica Paleoproterozoica juvenil en el Craton del Rio de la Plata (Uruguay), South American Symposium on Isotope Geology, 1, 20-26 July, 1999.

Raab, M. J., Brown, R. W., Gallagher, K. Carter, A., and Weber, K.: Late Cretaceous reactivation of major crustal shear zones in northern Namibia: Constraints from apatite fission track analysis, Tectonophysics, 349, 75-92, 2002.

Ramos, V. A.: The tectonics of the central Andes. in: Processes in continental lithospheric deformation, Geol. Soc. Am. Spec. Pap., 218, 31-54, 1988.

Rapela, C. W., Fanning, C. M., Casquet, C., Pankhurst, R. J., Spalletti, L., Poiré, D., and Baldo, E. G.: The Rio de la Plata Craton and the adjoining Pan-African/brasiliano terranes: Their origin 
sand incorporation into south-west, Gondwana Res., 20, 673690, 2011.

Riccomini, C., Turcq, B., and Martin, L.: The colônia astrobleme. in: ABEQUA/INQUA, International Symposium on global changes in South America during the Quaternary: past, present and future, São Paulo, 14 pp., 4-8 September, Excursion Field Guide, 1989.

Saalmann, K., Gerdes, A., Lahaye, Y., Hartmann, L. A., Remus, M. V. D., and Laufer, A.: Multiple accretion at the eastern margin of the Rio de La Plata craton, the prolonged Brasiliano orogeny in southern most Brazil, Int. J. Earth Sci., 100, 355-378, 2011.

Salamuni, E., Ebert, H. D., and Hasui, Y.: Morfotectônica da bacia sedimentar de Curitiba, Rev. Bras. Geoci., 34, 469-478, 2003.

Santos, J. O., Hartmann, L. A., Bossi, J., Campal, N., Schipilov, A., and McNaughton, N. J.: Duration of the Trans-Amazonian Cycle and its correlation within South America based on U-Pb SHRIMP geochronology of the La Plata craton, Uruguay, Int. Geol. Rev., 45, 27-48, 2003.

Siqueira-Ribeiro, M. C., Hackspacher, P. C., Ribeiro, L. F. B., and Hadler Neto, J. C.: Evolução Tectônica e Denudacional da Serra do Mar (SE/BRASIL) no limite entre o Cretáceo Superior e Paleoceno, utilizando análises de Traços de Fissão e U-TH/HE em Apatitas, Rev. Bras. Geom., 12, 3-14, 2011.

Tello, C. A. S., Hackspacher, P. C., Hadler Neto, J. C., Iunes, P. J., Ribeiro, L. F. B., and Paulo, S. R.: Recognition of cretaceous, Paleocene and Neogene tectonic reactivation through apatite fission track analysis in Precambrian areas of 10 southeast Brazil: association with the opening of South Atlantic Ocean, J. South Am. Earth Sci., 15, 765-774, 2003.
Teixeira, W., Renne P., Bossi, J., Campal, N., and Dagrella Filho, M.: $\mathrm{Ar}_{40} / \mathrm{Ar}_{3} 9$ and $\mathrm{Rb} / \mathrm{Sr}$ geochronology of the Uruguay Dike Swarm, Rio de la Plata Craton, Precambr. Res., 93, 153-155, 1999.

Tomazelli, L. J. and Villwock, J. A.: O cenozóico no Rio Grande do Sul: geologia da planície costeira, in: Geologia do Rio Grande do Sul, edited by: Holz, M. and De Ros, L. F., Porto Alegre: IG/UFRGS, 375-406, 2000.

Tinker, J., De Wit, M., and Brown, R. W.: Mesozoic exhumation of the southern Cape, South Africa, quantified using apatite fission track thermochronology, Tectonophysics, 455, 77-93, 2008.

Zalán, P. V., Wolffs, S., Conceição, J. C. J., Appi, V. T., Astolfi, M. A. M., and Marques, A.: The Paraná Basin, in: Interior Cratonic Basins, edited by: Leighton, M. W., Kolata, D. R., Oltz, D. F., and Eidel, J. J., AAPG, 51, 681-708, 1990.

Zerfass, H., Lavina, E. L., Schultz, C. L., Garcia, A. J. V., Faccini, U. F., and Chemale Jr., F.: Sequence stratigraphy of continental Triassic strata of southernmost Brazil: a contribution to southwestern Gondwana palaeogeography and palaeoclimate, Sediment Geol., 161, 85-105, 2003. 